\title{
Child-Friendly Educative Game Tools (APE) in 3Ps Perspectives
}

\author{
Senowarsito $^{1}$, Siti Musarokah ${ }^{1}$ \\ ${ }^{1}$ Universitas PGRI Semarang, JI. Sidodadi Timur No. 24 Semarang, Indonesia
}

\begin{abstract}
The consciousness and unconsciousness violence against children in learning process are still found in almost schools in Indonesia. They still place pupils as the object of teaching without paying much on how to fulfill student's needs, the need of getting knowledge, comfortableness, protection, and participation. One of the objectives of child-friendly education in early childhood is to facilitate early childhood with education game tools based on provision, protection, and participation. The study is carried out to identify the educative game tools (APE) used in Early Childhood Education and to know the feasibility of the educative game tools found in Early Childhood Education. To achieve the objectives, the approach used in the study was qualitative descriptive. The study was conducted in Early Childhood Education, and the sample was taken by using purposive sampling. In collecting the data, observation and interview used in the study. The data was then analyzed using flow model- reduction data, data display, and conclusion/verification. The results of the study show that wood and plastic-based educative game tools dominate game tools in early childhood education nowadays. However, Provision, Protection and Participation (3Ps) which aim at manifesting the fulfillment of the child rights in early childhood education have not fully implemented in educative game tools found. Therefore, it is necessary to create educative game tools based on 3Ps so that child-friendly learning in early childhood education is achieved through 3Ps-based educative game tools.
\end{abstract}

\section{Keywords: child-friendly learning; educative game tool (APE); early childhood education}

\section{INTRODUCTION}

The research results on early childhood education lately indicates that Educative Game Tools (APE) both traditional and modern ones seem effect positively on the students' competence and character. The first previous research which identified the effects of the development of traditional game tools in Kindergarten was conducted by Wati, Sukri and Wahyudi [1]. One of the results of their research shows that through the development of educative game tools, it effects on students' soft motoric skills, namely coordinating the movement of the fingers to hold educational toys, imitating the shape by using educational toys, and exploring the various media and activities. The next research on early childhood education was conducted by Wulandari and Hurustyanti [2]. They implemented many traditional games, some of which use traditional game tools. This research found that by using traditional game tools, the quality of honesty 
character enhances; it is reflected on the changing of children's individual character. The development of interactive multimedia-based educative game tools done by Purnama, Sunardi and Suryani [3] is the third previous research which has successfully implemented modern educative game tool. One finding of the research is that interactive multimedia-based educative game tool can enhance children' reading skill.

Early childhood education as the first learning stage of children should be conducted with the purpose to help the children grow both physically and spiritually so that they can have readiness in entering further education level [4]. Therefore, the education in early childhood should facilitate the children with some activities leading to the development of their motoric skills, such as exercising with the simple movement, learning to cut paper with the teacher mentoring, etc. In this stage of learning, the children are also introduced with the values of religiosity. For example, they learn to know their God, to understand the rules in their religion, to appreciate others who have different beliefs, etc. Moreover, all activities done by them are expected to enhance the educational, social and personality competence. In this case, the education for early child aims not only to make the children smart by having such high intelligence but also to develop social relationship with others. The development of the children's personality competence also become the concern of early childhood education.

From those explanation, the implementation of educative game tools does not always work well. Some challenges confront the teachers of early childhood education. As we know that the characteristics of early childhood learners are that they like playing a lot; their interest in game tools also change fast when they feel that the game tools they play are boring; and "the children's concentration can easily change" [2], etc. Therefore, teaching for early childhood learners is not easy. The creativity in teaching is really needed to make the learners comfortable and not easy to be bored.

In line with the topic of the study, however, the previous researchers have not reviewed whether or not the educative game tools they applied have fulfilled the rights of the child. It includes Survival rights, Development rights, Protection rights, and Participation rights [5]. We can highlight that all educative game tools used in teaching learning proses should implement the rights of the child in practice. By implementing child-friendly learning, the ideal outcomes of early childhood education can be well achieved. One of the example is building children's character [6].

Based on those description, this study mainly aims at identifying the use of educative game tools in early childhood education and the feasibility of educative game tools based on 3Ps (Provision, Protection, and Participation). In this case, the concept of 3Ps which is developed by Listyaning et. al. [7] is used to know if the educative game tools have fulfilled Provision, Protection, and Participation (3Ps).

\section{METHODS}

The data used in this study is qualitative data. The object of the research is all educative game tools used in five Play Groups (KB) and Early Childhood Education (PAUD) in Semarang. The technique used to get the sample is purposive sampling. There are some considerations in using the sampling, namely the location of schools which was chosen; it was determined based on west, north, east and south direction. 
Moreover, the schools which became the sample was determined not only the reputable schools but also ordinary schools.

Because this is qualitative study, we as the researchers are the instruments of the study as stated by Moleong [8]. In collecting the data, we collected through observation and interview. Observation was used to identify the types of Educative Game Tools (APE) and the feasibility of the APE found. Before observation was done, we prepared observation sheet in the form of table consisting of "Name of Educative Game Tools, Basic Material of the Game Tools, and Feasibility of the Game Tools". In finding out the feasibility of the traditional game tools we observed carefully whether the concept of Provision, Protection and Participation (3Ps) already exists in educational game tools found. Interview was used as the additional data collection to know deeply how the teachers use the game tools in teaching learning process. Thus, the result of interview can add some information needed in finding out the feasibility of APE.

The qualitative data then was analyzed by reducing the data, displaying the data, and making conclusion [9]. In reducing the data as the first step in analysis data, we selected the data needed and reduced the data which were irrelevant with the research objectives. Then we displayed the data in the table by grouping the APE found based on the basic material used. From result of the data display, finally we drew some conclusion.

\section{FINDINGS AND DISCUSSION}

\section{Types of Educative Game Tools in Early Childhood Education}

To find out the types of educative game tools used in early childhood education, we identified directly all educative game tools had and used by the early childhood education schools. In identifying the types of educative game tools used in early childhood education, we classified them into some classifications based on the basic materials used. TABLE I shows the kinds of educative game tools found.

\begin{tabular}{|c|c|c|c|}
\hline \multicolumn{4}{|c|}{\begin{tabular}{l|l}
\multicolumn{2}{c}{ IN EARLY CHILDHOOD EDUCATION } \\
Types of Educative & Names of educative Game Tools
\end{tabular}} \\
\hline & \multicolumn{2}{|c|}{ Game Tools } & \\
\hline \multirow[t]{2}{*}{1} & Plastic-Based & Educative & $\begin{array}{l}\text { a dish rack, an egg scale, toy cars, toy planes, a toy } \\
\text { motorcycle, toy }\end{array}$ \\
\hline & Game Tools & & $\begin{array}{l}\text { trucks, lego, animals, fruits, a tambourine, dolls, balls, } \\
\text { and a hairdryer }\end{array}$ \\
\hline \multirow[t]{2}{*}{2} & Paper-Based & Educative & $\begin{array}{l}\text { puzzles, a trumpet, flash cards, letter cards, a computer, a } \\
\text { cashier }\end{array}$ \\
\hline & Game Tools & & machine, an ATM machine, bags, hats, flags, and puppets \\
\hline \multirow[t]{3}{*}{3} & Wood-Based & Educative & $\begin{array}{l}\text { a marble game tool, blocks, toy cars, a date and month } \\
\text { block, }\end{array}$ \\
\hline & Game Tools & & $\begin{array}{l}\text { guitars, ice cream stick, traffic signs, puzzles, letter blocks, } \\
\text { shape }\end{array}$ \\
\hline & & & $\begin{array}{l}\text { puzzles, number blocks, body part boards, family } \\
\text { boards, a } \\
\text { vegetable puzzle, puppets, profession boards, a plane, } \\
\text { dakon, a sempoa, } \\
\text { a grinding machine, and kuda lumping }\end{array}$ \\
\hline
\end{tabular}


TABLE I, CONT.

\begin{tabular}{|c|c|c|c|}
\hline 4 & Iron-based & Educative & gamelan mini \\
\hline & Game Tools & & \\
\hline \multirow[t]{2}{*}{5} & Rattan-based & Educative & Hula-hoops \\
\hline & Game Tools & & \\
\hline \multirow[t]{2}{*}{6} & Animal & Skin-Based & Puppets \\
\hline & Educative Gan & Tools & \\
\hline \multirow[t]{2}{*}{7} & Natural & $\begin{array}{c}\text { Material- } \\
\text { Based }\end{array}$ & corns, dakon, angklung, shells, corals, sand and seeds \\
\hline & Educative Gan & Tools & \\
\hline \multirow[t]{2}{*}{8} & Cloth-Based & Educative & dolls and bags \\
\hline & Game Tools & & \\
\hline 9 & Sponge-Based & & shopping bags, animal cards, and number puzzles \\
\hline
\end{tabular}

From the TABLE I, we found nine types of educative game tools, namely plastic, paper, wood, iron, rattan, animal skin, natural material, cloth, and sponge-based educative game tools. It seems that wood and plastic-based game tools dominate game tools in early childhood education nowadays. In this case, there are various types of the game tools in these categorizations. However, from all game tools found, they cannot be categorized into educative game tools because there are some characteristics which should include in educative game tools. "Characteristics of Educative game tools in Kindergarten are namely 1) intended for children of kindergarten, 2) functioning to develop aspects of the development of kindergarten children, 3) used in various ways, forms and for various purposes of development or multipurpose, 4) safe for children, 5) designed to encourage activity and creativity, and 6) be constructive or generating something" [10].

\section{Feasibility of Educative Game Tools in Early Childhood Education}

The term of feasibility is often used in the researches related to business or economy as stated by Spacey, "Feasibility analysis is the process of confirming that a strategy, plan or design is possible and makes sense" [11]. In this study, the process of confirming was also done to know the feasibility of the Educative Game Tools. However, to determine the feasibility of Educative Game Tools (APE), we observed deeply whether or not the APEs found in Early Childhood Education are suitable for early child, and the principles of Provision, Protection, and Participation (3Ps) are implemented well in the APE itself. Provision is the availability of children's need for love and affection, food, health, education and recreation. Meanwhile, protection is the right of the child to get protection from threats, discrimination, punishment, etc. both physically and psychologically. Moreover, participation is the right of the child to act; in this case, students get the freedom to give opinions, questions, argue, and play an active role in the classroom or at school [7]. Then, we noted which educative game tools can be stated feasible. If the educative game tools found have provision, protection, and participation (3P) elements, they can be stated as feasible educative game tools, whereas if one or two elements of 3P are not included in the game tools, they can be categorized not worthy or less feasible.

In the first categorization, plastic-based educative game tools, we found thirteen types of educative game tools. They are a dish rack, an egg scale, toy cars, toy planes, a toy motorcycle, toy trucks, lego, animals, fruits, a tambourine, dolls, mini balls, houses 
and a hairdryer. Based on the identification of this category, all educative game tools found have provision because they give learning experiences for children; the teachers can use the game tools to educate early childhood, so early childhood can have certain competencies according to the learning objectives. However, in the category of plasticbased educative game tools, we found some game tools do not have protection element. For example, they are mini balls. In terms of materials used in game tools, we do not know whether plastic used as the basic material of the game tools is waste plastic containing chemicals or not. Because when we smell the game tools, they sting. It can be stated that the game tools are not safe for children. Thus, not all plastic-based educative game tools are appropriate to be used for children. For the last element of 3Ps, participation, not all plastic-based educative game tools found are implemented cooperatively. Therefore, the implementation of participation element of plastic-based educative game tools is less feasible to be used in early childhood education.

The next educative game tools are paper-based game tools. We found puzzles, a trumpet, flash cards, letter cards, a computer, a cashier machine, an ATM machine, bags, hats, flags, and puppets in the category. All kinds of paper-based game tools have implemented provision because they give the students learning experiences. Moreover, all kinds of paper-based educative game tools are safe enough for children, so the game tools meet the element of protection. However, the element of participation is not yet fully feasible because some paper-based educative game tools can only be played individually. It means that only a few children have the opportunity to play the game tools. In other words, to include participation element in the game tools, they should be played cooperatively, so the children have the same right to play them.

The next categorization is wood-based educative game tools. We found a marble game tool, blocks, toy cars, a date and month block, guitars, ice cream stick, traffic signs, puzzles, letter blocks, shape puzzles, number blocks, body part boards, family boards, a vegetable puzzle, puppets, profession boards, a toy plane, dakon, a sempoa, a grinding machine, and kuda lumping. Provision has been included in all kinds of woodbased educative game tools. Children can have various competences through these kinds of game tools. However, they still have weaknesses. For example, because the wood-based educative game tools have hard basic material, this requires careful supervision from the teachers when the children use them; otherwise, the children will hurt themselves or their friends. Therefore, in the protection element, wood-based educative game tools have not been fully feasible. For participation element, most wood-based educative game tools are played cooperatively except a toy plane and kuda lumping. Nevertheless, wood-based educative game tools found have not been fully feasible based on the participation.

Provision is also included in the next categorization of educative game tools, ironbased educative game tools. In this category, we found gamelan mini which is one of traditional musical instrument. Through this tool, the children can learn both the way to play the instrument and counting the irons used in the instrument. Accordingly, from provision side, the musical instrument is feasible. However, based on protection, the teachers can accompany the children when they play it because the way to play the instrument is by beating the stick on it. If it is not supervised by the teacher, the children will hit the other child. Therefore, from the side of protection, the iron-based educative game tool is not fully safe or not fully feasible. In addition, from the side of participation, although gamelan can be played cooperatively, but it is usually played 
individually. Thus, this kind of musical instrument from the side of participation is less feasible.

Hula-hoops are found in the identification as rattan-based educative game tools. However, most teachers do not use these kinds of educative game tools as a tool or media to teach the students. These function as game tools only; therefore, from provision side these game tools are not feasible. However, from the protection side these game tools are safe for children if they play them carefully. Otherwise, the game tools will hit the body or head of their friends. Thus, from protection side, the game tools found are less feasible. Moreover, from the side of participation, they are less feasible because hula-hops are played individually, and all children cannot cooperate together unless the teacher manages the rules of the game.

In the sixth categorization, animal skin-based educative game tools, we found puppets. From the side of provision these puppets can be used as media to teach early learners, and they are interesting enough for early learners. For example, the teacher can tell the story through the puppets, so the pupils can have some competencies, such listening skill, the competence to comprehend the content of the story, etc. Therefore, from the side of provision these animal skin-based educative game tools are feasible. Moreover, from the side of protection they are also feasible because the sticks used to play wayang are safe enough for children. Meanwhile, from participation side, through these educative game tools the pupils have less opportunity to use them because teachers usually use the game tools by themselves. Thus, they are less feasible from participation side.

The seventh categorization, nature-based educative game tools, consists of corns, seeds, dakon, angklung, shells, corals, and sand. From the provision side, most kinds of real object can help the children to understand such objects easier and faster because they feel the object directly. Therefore, from provision side, they are feasible enough. However, although educative game tools which are from nature make early learners easier to understand such material, but from protection side, these have many weaknesses. For example, they are corns and seeds; because they have small size, they are easily swallowed by early children. Dakon, a traditional game tools found is made from coconut shell, and it has sharp side, so it can also make children's parts of body easily hurt. Angklung, one of traditional musical instruments which has basic material from bamboo can hurt children' parts of body as well. Moreover, shells and corrals can hurt children' hands or other parts of their body easily, and the sand can also endanger children's eyes when it is not used carefully. Therefore, all nature-based educative game tools found are not categorized feasible based on protection side. Meanwhile, from the participation side most nature-based educative game tools can be played cooperatively.

The eight and the ninth categorization, cloth and sponge-based educative game tools, from provision perspective they can be categorized feasible. We found dolls and bags belong to cloth-based educative game tools, and shopping bags, animal cards, and number puzzles belong to sponge-based educative game tools. From protection perspective both cloth and sponge-based educative game tools are the safest among other educative game tools, but the cleanliness of the game tools should be maintained regularly. It means that from protection side these game tools are feasible. However, from participation side, not all cloth and sponge-based educative game tools are feasible because some students do not have an opportunity to use the game tools. 


\section{CONCLUSION}

The conclusion of the study can be drawn that there are nine types of educational game tools found; wood and plastic-based educative game tools dominate game tools in early childhood education nowadays. Moreover, Provision, Protection and Participation (3Ps) which aim at manifesting the fulfillment of the child rights in early childhood education have not fully implemented in educative game tools found because from the 3Ps perspective some of them are less feasible. Therefore, it is necessary to create educative game tools based on 3Ps so that child-friendly learning in early childhood education is achieved through 3Ps-based educative game tools.

\section{REFERENCES}

[1] Wati, S., M. Syukri, and Wahyudi. 2013. "Pengembangan Alat Permainan Edukatif dalam Pembelajaran Model Webbed pada Anak Usia 5-6 Tahun," pp. 1-15

[2] Wulandari, R. S. and H. Hurustyanti. 2016. "Character Building Anak Usia Dini Melalui Optimalisasi Fungsi Permainan Tradisional Berbasis Budaya Lokal,” Journal Indonesian Language Education and Literature Vol. 2, No. 1. pp. 22-31

[3] Purnama, F., Sunardi, N. Suryani. 2015. "Pengembangan Alat Permainan Edukatif (APE) Bahasa Indonesia Berbasis Multimedia Interaktif," Teknodika, Volume 13, Nomor 2, September 2015, pp. 29-36.

[4] Indonesian Rules Number 20 Year 2003 on National Education System Article 1 Sub-Article 14.

[5] UN Convention on the Rights of the Child.

[6] Risminawati and S. N. Rofi 'ah. 2015. "Implementasi Pendidikan Ramah Anak dalam Pembentukan Karakter Siswa Kelas Rendah SD Muhammadiyah Program Khusus Kota Barat Tahun Pelajaran 2013/ 2014," Profesi Pendidikan Dasar Vol. 2, No. 1, Juli 2015, pp. 68 - 76.

[7] Sumardiyani, L. \& at all. "Child Friendly Teaching Model (CFTM)," Semarang: IKIP PGRI Semarang Press.

[8] Moleong, L. J. 2007. "Metodologi Penelitian Kualitatif.” Bandung: PT Remaja Rosdakarya.

[9] Miles, M. B. and A. M. Huberman. 1994. "Qualitative Data Analysis" (2nd edition). Thousand Oaks, CA: Sage Publication.

[10] Zaman, B. 2007. "Media dan Sumber Belajar TK.” Jakarta: Penerbit Universitas.

[11] Spacey, J. 2017. "7 Types of Feasibility Analysis." Retrieved at https://simplicable.com/new/feasibility-analysis 